\title{
Field validation of senesced banana leaf extracts for trapping banana weevils on smallholder banana/plantain farms
}

Article

Accepted Version

Abagale, S. A., Braimah, H., Osafo-Acquaah, S., Powers, S. J., van Emden, H. F., Birkett, M. A., Pickett, J. A., Sanda, U. L. and Vuts, J. (2021) Field validation of senesced banana leaf extracts for trapping banana weevils on smallholder banana/plantain farms. Journal of Applied Entomology, 145 (12). pp. 26-35. ISSN 0931-2048 doi:

https://doi.org/10.1111/jen.12838 Available at https://centaur.reading.ac.uk/93985/

It is advisable to refer to the publisher's version if you intend to cite from the work. See Guidance on citing.

To link to this article DOI: http://dx.doi.org/10.1111/jen.12838

Publisher: Wiley-Blackwell

All outputs in CentAUR are protected by Intellectual Property Rights law, including copyright law. Copyright and IPR is retained by the creators or other copyright holders. Terms and conditions for use of this material are defined in the End User Agreement. 


\section{CentAUR}

Central Archive at the University of Reading

Reading's research outputs online 


\section{Abstract}

2 Palm wine alcohol extract of senesced banana leaf material, Musa spp., was tested for its 3 efficacy in open field trapping of the banana weevil, Cosmopolites sordidus in Ghana from

4 June to August 2015. Modified pitfall and bottle traps were baited with either individual 5 treatments, i.e. palm alcohol extract, C. sordidus aggregation pheromone or pseudostem, or 6 with combinations of extract plus aggregation pheromone or extract plus pseudostem. The 7 combination of extract plus aggregation pheromone was able to lure more weevils into traps 8 compared to the respective individual lures. There was a 2.1-fold increase in mean catch per 9 week when the palm alcohol extract was used in combination with pheromone compared to using pheromone alone, and a corresponding 2.6-fold increase when the extract was used with pseudostem in traps. There was no statistically significant interaction between the palm alcohol extract (presence or absence) and treatment (pheromone or pseudostem), but the best combination for maximal catches of adult banana weevils was a combination of palm alcohol extract with aggregation pheromone. Management of banana weevils with attractive banana leaf extract has important practical applications in parts of the world where other management options are too expensive or commercial treatments are in short supply, but where leaf material is cheap and readily available for local use by smallholder farmers.

Keywords: Musa spp, Cosmopolites sordidus, Ghana, lure, TAL trap, Voltic trap 


\section{Introduction}

Bananas and plantains are of great economic importance in most regions of tropical and subtropical Africa. All year round production of bananas ensures a continuous supply of food and income to the farmer, making bananas a major food security crop in the region (Ocan, Mukasa, Rubaihayo, Tinzaara \& Blomme, 2008) and an important cash and subsistence crop in most tropical and subtropical regions of the world (Ortiz \& Swennen, 2014). According to estimations by the Food and Agriculture Organization (FAO), world total exports of banana accounted for 15.9 million tonnes in 2004 (Kumar, Jain, Meena \& Sen, 2015) In 2018, global exports of bananas, excluding plantain, reached a record high of 19.2 to 23.3 million tonnes (FAO, 2019; Mordor Intelligence, 2019) but in Africa there was an estimated drop of 9 percent below the level of 2017 exports (FAO, 2019). Banana export from Ghana has grown from about 3,000 tonnes per year in 2007 to over 70,000 tonnes in 2017 , positioning the commodity as second to cocoa and oil palm (Ghanaweb reports, 2018). The largest export portion (43\%) of banana from Ghana in 2015 was to The United Kingdom, followed by Belgium in second place (Ghana Export Promotion Authority, 2017). Currently, Ghana is one of the Africa Caribbean Pacific (ACP) countries that have concluded negotiations on an Economic Partnership Agreement (EPA) for supply of bananas to countries in the European Union (FAO, 2019).

Approximately $98 \%$ of world banana production is in developing countries, with bananas mainly being imported by developed countries (Kumakech, 2008). The estimated worldwide average total increase of banana exports was $43.3 \%$ in 2019, over a five-year period from 2015. Latin America excluding Mexico plus the Caribbean had the greatest monetary value of banana exports in 2019 (\$8.3 billion, 56.7\%), followed by Europe (17.5\%), Asia (15.6\%), Africa (5.2\%), North America (4.9\%) and Oceania (0.004\%) (Workman, 2020).

Sustainable production of bananas and plantains is constrained by many biotic factors (Hallam, 1995) that significantly reduce crop yield, including insect pests and pathogens such 
as weevils, nematodes, black sigatoka disease, fusarium wilt and banana xanthomonas wilt disease. Most of the banana pests and pathogens are transmitted through suckers from infected parent plants and from one farm to another through the exchange of suckers, a common practice among smallholder farmers (Macharia, Kagundu, Kimani \& Otieno, 2010). The banana weevil, Cosmopolites sordidus Germar (Coleoptera: Curculionidae) has been cited as one of the most challenging constraints to banana and plantain production, particularly on smallholder farms (Price, 1994; Gold, Pena \& Karamura, 2001; Foagain, Messiaen \& Foure, 2002; Twesigye et al. 2018). C. sordidus is native to Malaysia and Indonesia but is found in nearly all bananagrowing areas of the world (Gold et al. 2001; Reddy, Cruz, Naz \& Muniappan, 2008). The weevil has been reported as one of the foremost pests in most bananas growing regions (Stover \& Simmonds, 1987), attacking all types of bananas, including those destined for dessert and brewing industries, highland bananas and plantains. Management strategies for $C$. sordidus vary in efficacy and convenience, and currently include the use of synthetic pesticides (Sponagel, Diaz \& Cribas, 1995); cultural control methods such as farm sanitation (Masanza, Gold, van Huis \& Ragama, 2005), and use of pseudostem traps (Gold, Okech \& Nokoe, 2002); biological control with entomopathogens (Treverrow, Bedding, Dettmann \& Maddox, 1991; Nankinga \& Moore, 2000) or myrmicine ants (Castineiras \& Ponce, 1991); planting of host plants with resistance (Kiggundu, Gold, Labuschagne, Vuylsteke \& Louw, 2003); use of botanical pesticides such as neem extracts (Musabyimana, Saxena, Kairu, Ogol \& Khan, 2001), and mass trapping with aggregation pheromone lures (Alpizar, Fallas, Oehlschlager, Gonzalez \& Jayaraman, 1999; Tinzaara et al. 2005). Large-scale control of C. sordidus is currently achieved by chemical methods, while cultural controls remain highly valuable in preventing the establishment of the pest. Cultural control methods are also the main available means of management of the pest by smallholder farmers and growers, while biological control methods such as the application of arthropods and fungi in integrated pest management strategies are also being developed (Braimah \& van Emden, 1999). In Asia, classical biological control of 
the weevil using natural enemies has so far been unsuccessful and the use of opportunistic, generalist predators have had limited efficacy (Waterhouse and Norris, 1987; Koppenhofer et al., 1992). Ants have been reported to help control the weevil in Cuba, but their effects elsewhere are unknown (Castineiras and Ponce, 1991). Effective strains of microbial agents have also been reported, but their use is constrained by the need of economic mass production and delivery systems (Gold, Pena \& Karamura, 2003).

The attractiveness of pheromone-based lures for many insect species can be enhanced through combination with host plant-derived volatiles (Tewari, Leskey, Nielsen, Piñero \& Rodriguez-Saona, 2014). Combination effects between pheromones and plant odour have been reported to be a common feature for weevils (Curculionidae) and possibly more widely amongst Coleopteran species (Hugo, Kenju, Toru \& Klaus, 1998; Wertheim, van Baalen, Dicke \& Vet, 2005; Vidal, Moreira, Coracini \& Zarbin, 2019). Adult C. sordidus have been shown to orient to both the male-produced aggregation pheromone and host plant volatiles (Tinzaara, Dicke, Van Huis \& Gold, 2002). In our earlier work, senesced banana leaves were found to be attractive to adult $C$. sordidus, with the active component from volatile collections being identified, via behaviour (olfactometer) assays and coupled GC-electrophysiology, as $(2 R, 5 S)$ theaspirane (Braimah \& Van Emden, 1999; Abagale et al. 2018a). Furthermore, a mixture of the theaspirane isomers was shown to enhance the activity of the aggregation pheromone (Abagale et al. 2018a). Additionally, palm alcohol extract of senesced leaf material was shown to be equally attractive as senesced leaf material, suggesting that the extract could be suitable for deployment in new trapping systems aimed at banana weevil management (Abagale et al. 2018b). Here, we report on open field trapping of banana weevils in Ghana using palm alcohol extract of dead banana leaf, the aggregation pheromone, pseudostem, and combinations thereof, to investigate the potential for interaction between the treatments in the field, and 
assess the additive/synergistic potential for the use of palm alcohol extract in weevil trapping systems using two trap designs.

\section{Materials and Methods}

2.1 Trap baits. Palm (Elaeis guineensis) alcohol extract of senesced banana leaf material (of the common and major type of banana grown in Ghana, (Cavendish bananas)) required for field trapping experiments was prepared as previously described (Abagale et al. 2018b), by crushing banana leaf material $(100 \mathrm{~g})$ into palm alcohol $(50 \mathrm{ml})$. The mixture was kept for 24 hours at ambient temperature before being decanted into storage vials. Cosmolure (P160-Lure), containing the banana weevil aggregation pheromone (Beauhaire et al. 1995), sordidin, was purchased from ChemTica International, Costa Rica. Samples of fresh banana pseudostems (Figure 1C) were collected from growing plants in banana fields at the site of trapping experiments.

2.2 Banana weevil traps. Two types of traps were used in the field trapping; a CSALOMON® pitfall trap codenamed TAL (Plant Protection Institute, Budapest, Hungary) (Figure 1A) and a Voltic drinking bottle trap (Figure 1B). The TAL trap is a modified pitfall trap with a cover that protects it from rainwater collection. To set up the trap, it is usually placed on the soil surface without digging into the soil and also without adding a killing liquid. It has consistent sensitivity with a very high holding capacity of weevil catch (Tóth et al., 2002). The catch container of the TAL trap is a pale pink plastic tray $(7 \times 17.5 \times 11.5 \mathrm{~cm})$ that, for this study, was sunk into a shallow hole in the soil. A roof made of a folded transparent plastic sheet is placed above the container, and two vertical off-white side sheets on the ground are attached at soil level, thus providing a smooth surface for weevils entering the trap and leading them into the container. The Voltic bottle trap (Abagale et al., 2017) was made using two $1.5 \mathrm{~L}$ 
empty water bottles purchased from Kumasi Central Market, Ghana. The lower portion of one bottle was cut to provide a $10 \mathrm{~cm}$ high weevil collection receptacle. Two vents were made on opposite sides of the second bottle, each by cutting the bottle on three edges at a height of 14.5 $\mathrm{cm}$ from the mouth such that the resultant flap opened towards the fourth side (bottom). Each vent was approximately $36 \mathrm{~cm}^{2}$. When in use, the flap was lifted up towards the outside of the trap to serve as protection against direct entry of rainwater into the trap. A narrow hole was created on the bottom of the second bottle for use in hanging the bait. To complete the trap, this second bottle was then inserted upside-down into the receptacle half made from the other bottle. In the field, the trap was buried so that the lower edge of the cut vent was at ground level, and the bait was hung from the top so that it came into level with the opening.

2.3 Baiting of traps. The TAL and Voltic traps (figure1) were baited with either individual treatments, i.e. palm alcohol extract of senesced banana leaves, or the use of aggregation pheromone or pseudostem, or combinations of extract plus pheromone or extract plus pseudostem, giving 10 treatment combinations altogether. This formed an extract only (control lure) plus a 'two treatments (pheromone and pseudostem) by two levels of extract (presence and absence)' factorial set, by two types of traps (TAL and Voltic bottle). For treatment combinations involving the pheromone and pseudostem, those with palm alcohol extract were the test treatments and those without were the corresponding controls. The traps were baited by applying palm alcohol extract (ca $1 \mathrm{ml}$ ) of senesced banana leaves using a syringe and needle. The extract (lure) was applied at trap set and re-applied every two weeks over the period of trapping. Controls were baited using only the solvent of extraction.

For the Cosmolure, the dispenser was hung from the roof of the traps using the flexible copper wire. For the palm alcohol extract, flexible copper wire was also used to suspend a $0.50 \mathrm{~g}$ piece of polyurethane based synthetic latex foam (made in Ghana) as dispenser. The dispensers were 
hanged from the top of TAL and Voltic traps (Abagale et al., 2017). The palm alcohol extract

of banana bait was applied on the surface of the foam. In the use of Cosmolure, the bait

dispenser was fastened to the copper wire. The baits were suspended to fall in line with openings in each trap to facilitate diffusion of the bait odours to the outside to attract weevils into the trap. It was also ensured that the dispensers did not touch walls of the trap.

The traps with pseudostem were made of fresh material. Ca. $25 \mathrm{~cm}$ lengths of pseudostem made from fresh plantain/banana were cut and split in half. Each half was enough for a trap.

Smallholder farmers already use pseudostem for trapping the weevils as indicated in previous studies (Jayaraman et al., 1997; Gold et al., 2002).

2.4 Field trapping and trapping sites. Trapping was done on five fields located in the Ashanti region of Ghana $\left(6^{\circ} 41^{\prime} 18^{\prime \prime} \mathrm{N} ; 1^{\circ} 37^{\prime} 27^{\prime \prime} \mathrm{W}\right)$ between June and August 2015; two at the College of Agriculture (fields 1 \& 2), one each at Kwadaso and Mwamase near Kwadaso (fields 3 \& and no more than $10 \mathrm{~km}$ apart. There were five traps of one type (Voltic or TAL) in each field, one trap for each bait treatment. Each field contained one replicate of each treatment associated with one type of trap. There was no blocking. Each field was a main-plot in a split-plot design, the main plots providing the overall replication of the trap by lure treatment combinations. There was a single experiment, and underlying variation from the single experiment was used to make assessment of differences between treatments overall. There were no blocks, only main-plots with the trapping positions as split-plots. Traps were randomly allocated to fields as it was obviously not possible to start off with the same numbers of weevils per field for comparing trap by lure combinations. Geographically separate populations may respond differently to on-farm conditions or insect ecology (Braimah and van Emden, 2002; 

seeing that they were in the same geographic location.

Traps were arranged randomly in each field, maintaining at least $20 \mathrm{~m}$ between each trap and $10 \mathrm{~m}$ from the boundary of the field. The traps were checked weekly for 12 weeks (fields 1,3 and 4), seven weeks (field 2) or five weeks (field 5). Hence, there were three replicates of treatments with Voltic traps (for 12, 7 and 5 weeks, fields 4, 2 and 5) and two replicates of treatments with TAL traps (for 12 weeks, fields 1 and 3) (see Table 4). Replication was applied over separate fields. The experimental fields were not large enough to accommodate more than 5 traps per field. Thus it was experimentally necessary to apply different treatment factors to the different sized experimental areas. Trap type was therefore assigned to fields and lure treatments to within fields using the split-plot design (Jones and Nachtsheim, 2009; Arnouts, 2018). There were unequal numbers of weeks per field, but to account for this situation the average catch per week is analysed, and weighted for the number of weeks $(12,7,5$; or 9 for the palm alcohol extract of banana leaf treatment in fields 1, 3 and 4).

Weevils captured were counted and recorded, and the total weevil capture per trap calculated. Average weevil catch per week for each treatment combination in each field was calculated, and the overall mean catch for each trap type was also calculated. All fields were part of one blocking, but they were of insufficient size to allow all 10 treatment combinations (trap type by bait treatment) in each one. Thus, fields were seen as main plots with one type of trap in each field, and with the baits as split-plot treatments. Subsequent analysis (Table 3) accounted for this design. 
2.5 Statistical analysis. Weighted analysis of variance (ANOVA) was applied to the average catch per week data, weighting for the number of weeks, taking account of the different fields and testing (F-tests) for the main effects and interactions between the factors of type of trap (TAL or Voltic bottle), lure treatment (pheromone or pseudostem) and extract (presence or absence), nesting out the extract-only lure from the two by two factorial set of treatment combinations. A natural logarithmic transformation was applied to the data to account for heterogeneity of variance across the treatment combinations. Checks on residuals (see Figure 2) revealed that, under the transformation, the assumptions of the analysis had been met. Given the ANOVA, appropriate tables of means were output, for comparison using the standard error of the difference (SED) between means, thus invoking the least significant difference (LSD) at the $5 \%$ level of significance. The GenStat $\left(17^{\text {th }}\right.$ edition, (C) VSN International Ltd, Hemel Hempstead, UK) statistical package was used for this analysis. It was noted that the statistical requirement of transformation of data did not alter the fact that the effect of the treatments was shown by the means of the untransformed data, and these means were therefore presented, but with the transformed means on which statistical tests were based, given the results of ANOVA, being included in brackets and italicised.

\section{Results}

Table 1 shows the total number of adult banana weevils caught in each trap for each of the five different treatments, and the percentage of total weevil capture over treatments either with or without pseudostem, whilst Table 2 shows the mean weevil catch per week in each of the five fields using the five different treatments. Figure 3 shows the average weekly catch for 
and additive. There was also no effect of type of trap (TrapType) or interaction of this factor

with the others. We also note that these same overall results were obtained when omitting the data from fields 2 and 5, for which trapping ran for less than 12 weeks. The means for the main effect of extract were: 4.239 (transformed data mean: 0.73) without extract and 8.862 (1.54) with extract $(n=10, \operatorname{SED}=0.204$ on $12 \mathrm{df} ; \operatorname{LSD}(5 \%)=0.445)$. These means show that there was approximately a 2.1-fold increase in mean catch per week through using the extract. The means for the main effect of lure treatment were also calculated for the pheromone and for pseudostem lures. These means show that there was approximately an 11-fold increase in mean catch per week through using pheromone compared to pseudostem. Although there was no statistically significant interaction between the two factors, the best combination for maximal catch was most certainly the pheromone with the extract; this gave a mean of $16.178(2.74)$, compared to 7.888 (2.05) for the pheromone without the extract ( $\mathrm{n}=5$, a 2.1-fold increase).

The corresponding results for pseudostem were $1.546(0.34)$ with the extract and $0.59(-0.59)$ without the extract ( $\mathrm{n}=5$, a 2.6-fold increase). However, even though there appeared to be substantially more than an additive effect involving the treatments, it was not robust enough to be statistically significant.

\section{Discussion}

It has been postulated that combinations of species-specific pheromone and host plant volatiles may interact synergistically to attract $C$. sordidus (Budenberg, Ndiege, Karago \& Hansson, 1993; Jayaraman et al. 1997). Preliminary studies in the laboratory have also 
indicated that host plant volatiles may enhance the aggregation pheromone (Tinzaara, Dicke,

244 Van Huis, Van Loon \& Gold, 2003), and our recent work has demonstrated that a mixture of

245 isomers of theaspirane, identified from senesced banana leaf material as a banana weevil

246 attractant, improves the activity of the aggregation pheromone (Abagale et al. 2018a).

247 Generally, there was large variation in the total number of weevils caught in a given type of

248 trap with different lures from the same field (Table 1). Correspondingly, there were differences

249 in the overall total numbers of weevils caught in all traps containing different types of lures.

250 Thus, comparing the three non-pseudostem treatment combinations, i.e. pheromone alone,

251 palm alcohol extract alone and pheromone with extract, $61.1 \%$ of the total weevils captured

252 were lured into traps containing the combination of pheromone and extract, while $8.5 \%$ and

$25330.4 \%$ of the total weevils were lured into traps containing the extract alone and pheromone

254 alone respectively. For the treatments involving pseudostem, traps with pseudostem treated

255 with the palm alcohol extract lured $72.1 \%$ of the weevils captured, whilst traps with untreated

256 pseudostem attracted $27.9 \%$ of the pseudostem-lured weevils.

Studies on the banana weevil show that various human and natural factors influence

weevil capture in traps (Braimah and van Emden, 2002; Gold et al., 2001, 2002; Tinzaara et

al., 2002; Zhu and Park, 2005; Dahlquist et al., 2007). Adult banana weevils have also been

shown to orient to both host plant volatiles and their aggregation pheromone (Tinzaara et al.,

2003), though the distance over which the weevils can be influenced is unknown (Gold et al.,

1999). Weevils could therefore move within and between fields (Dahlquist et al., 2007).

Therefore, even though geographical influences are real, field trapping has previously been

deployed to study how trap designs, and bait material could influence the capture of weevils

(Zhu and Park, 2005). Also in another study, cropping systems in different geographical

locations were reported to be similar (Somarriba and Harvey, 2003), but the rate of weevils 
Therefore, any geographic or on-farm influences in our trapping experiment were off set and the same geographical location and thus enabled robust assessment of the performance of the lures. Attraction of the weevils could therefore arise mainly from the observed luring activity of the aggregation pheromone and host-derived cues without excess variation from other extraneous sources. The extent of the observed field-to-field variation can therefore be explained in terms of the different periods of time (number of weeks) over which assessment was made for two of the fields compared to the other three (12 weeks for fields 1,3 and 4 , seven weeks for field 2, five weeks for field 5) and the varying numbers of total weevils per week over weeks (Table 4). That notwithstanding, the comparative outcome of the ANOVA of to produce consistent results. A study in Costa Rica reported that pseudostem traps baited with aggregation pheromone caused a 5-10-fold increase in attractiveness to weevils (Alpizar \& Fallas, 1997). In another study, using olfactometry experiments, Tinzaara et al. (2002) observed that a greater number of weevils responded to fermented banana tissues combined with the aggregation pheromone compared to the individual treatments. Other studies also indicated that banana extract and host plant extract enhanced pheromone attractiveness to weevils when used 
However, during pheromone trap trials in South Africa, trap catches were reported to be greater for traps with lures containing the pheromone than lures containing both the pheromone and a plant kairomone (De Graaf, Govender, Schoeman \& Viljoen, 2005). Also, a study in tropical Costa Rica reported that pseudostem traps and pseudostem traps baited with pheromone attracted an equal sex ratio of weevils (Jayaraman et al., 1997). The results of our present study suggest that palm alcohol extracts of senesced banana leaf material can enhance the attractiveness of the aggregation pheromone to adult banana weevils, and that weevil populations can be trapped through deployment of leaf extracts alone. This suggests that either approach is suitable for use in banana weevil management, with the latter being potentially affordable for use by smallholder banana/plantain farmers, especially since leaf material and palm alcohol are both affordable and available at no, or low cost. Further studies are planned to undertake field trapping experiments on a wider scale in Ghana and demonstrate the lowcost extraction and trapping technology to smallholder banana/plantain farmers.

In summary, palm alcohol extracts of senesced banana leaf material and the banana weevil aggregation pheromone were able to lure more weevils into modified type TAL and Voltic traps, and a combination of extract and pheromone lured a greater number of weevils into traps compared to the respective individual lures. The results showed that there was a significant main effect of the presence of extract and a main effect of the lure treatment (pheromone or pseudostem) used, but no interaction between the two factors, indicating that the two effects were independent and additive. However, there was at least some synergy between the extract and either the aggregation pheromone or pseudostem, as the extract increased the attractiveness of both the aggregation pheromone and pseudostem to adult banana weevils. Interaction of the bait materials were independent of the differences in trapping durations since the number of weevils caught in each case was averaged to give per-week values for analysis. In Table 4, for each field (sub-table), the overall mean per week (over $n=5$ 
or 4 traps) and standard error (SE) as well as the overall mean and SE of these weekly means has been calculated and transformed into trap type by treatment means (Figure 3). The significant differences in the catch of weevils per week in TAL and Voltic traps indicate the variation of effectiveness of the different baits and their combinations. The significant additive effect in both TAL and Voltic traps is clear (Figure 3).

This study, along with our previous work (Abagale et al. 2018a, 2018b), provides underpinning science for use of senesced leaf extract in banana weevil management and provides a chemical marker for quality assurance and control if the envisaged management system breaks down. From an economic perspective, banana and plantain farmers could be encouraged to develop the production of leaf extracts for crop protection, thereby not only providing economic and social benefits through enhanced banana and plantain production, but also by generating income from a new product.

However, differences in climatic conditions and variegation of banana weevil species may not necessarily permit success of the technology in other geographic locations. The study area has a tropical climate, with much rainier summers than winters with temperature averages of $26.3^{\circ} \mathrm{C} \mid 79.3^{\circ} \mathrm{F}$ and annual rainfall of $1448 \mathrm{~mm} \mid 57.0$ inches. A repeat of this study in other banana/plantain growing areas such as Central America and Asia is therefore required.

\section{Conflict of Interest Statement}

The authors have declared no conflicts of interest

\section{Author Contributions}

- SAA, HB, SOA, MB and JAP conceived research.

- SAA, HB and UIS conducted experiments.

- JV contributed TAL traps. 
- SAA, SJP and HvE analysed data and conducted statistical analyses.

- SAA and MB wrote the manuscript.

- $\mathrm{HB}, \mathrm{MB}$ and JAP secured funding.

- All authors read and approved the manuscript.

\section{Data Availability Statement}

All data and materials used in the study are either available from the corresponding author by request or have been used in this publication. Experimentally obtained raw data have also been presented in the current article.

\section{References}

Abagale et al.. A Study of Semiochemicals in Leaves of Musa species (Banana/Plantain) for Integrated Management of the Banana Weevil, Cosmopolites sordidus, (GERMA, 1824) (Coleoptera: Curculionidea), PhD thesis, Department of Chemistry, KNUST, 2017.

Abagale, S.A., Woodcock, C.M., Hooper, A.M., Caulfield, J.C., Chamberlain, K., Acquaah, S.O., Van Emden, H., Braimah, H., Pickett, J.A. \& Birkett M.A. (2018a). (2R, 5S)-Theaspirane identified as the major kairomone for the banana weevil, Cosmopolites sordidus from attractive senesced leaves of the host banana, Musa spp. Chemistry: A European Journal 24, 9217-9219.

Abagale, S.A, Woodcock, C.M., Caulfield, J.C., Chamberlain, K., Acquaah, S.O., Van Emden, H., Braimah, H., Pickett, J.A. \& Birkett, M.A. (2018b). Attractiveness of host banana leaf materials to the banana weevil, Cosmopolites sordidus in Ghana for development of field management strategies. Pest Management Science 75, 549-555. 
367 Alpizar, D. \& Fallas, M. (1997). Pheromone trapping system. Ministry of Agriculture, 368 Guapiles, Costa Rica.

369

Alpizar, D., Fallas, M., Oehlschlager, A.C., Gonzalez, L.M. \& Jayaraman S. (1999).

Pheromone-based mass trapping of the banana weevil, Cosmopolites sordidus (Germar) \& the

West Indian sugarcane weevil Metamasius hemipterus L. (Coleoptera: Curculionidae) in banana \& plantain. Memorias XIII Reunion ACORBAT, 23-27 November 1998. Guayaquil. pp. 515-538.

375

Anderbrant, O., Löfqvist, J., Hedenström, E., Bång, J., Tai, A. \& Högberg, H.-E. (2010). Field response of male pine sawflies, Neodiprion sertifer (Diprionidae), to Sex Pheromone Analogs in Japan and Sweden. Journal of Chemical Ecology, 36, 969-977.

Beauhaire, J.P., Ducrot, H., Malosse, C., Rochat, D., Ndiege, I.O. \& Otieno, D.O. (1995).

Identification and synthesis of sordidin, a male pheromone emitted by Cosmopolites sordidus. Tetrahedron Letters, 36, 1043-1046.

Braimah, H. \& van Emden, H.F. (1999). Evidence for the presence of chemicals attractive to the banana weevil, Cosmopolites sordidus (Coleoptera: Curculionidae) in dead banana leaves. Bulletin of Entomological Research, 89, 485-491.

Braimah, H. \& van Emden, H.F. (2002). Effects of soil water content and history of cultivation on the foraging behaviour of the banana weevil, Cosmopolites sordidus (Germar, 1824). Agriculture and Food Science Journal of Ghana, 1, 65-73. 
392 Budenberg, W.J., Ndiege, I.O., Karago, F.W. \& Hansson B.S. (1993). Behavioral and 393 electrophysiological responses of the banana weevil Cosmopolites sordidus to host plant 394 volatiles. Journal of Chemical Ecology, 19, 267-277.

396 Castineiras, A. \& Ponce, E. (1991). Efectividad de la utilizacin de Pheidole megacephala 397 (Hymenoptera: Formicidae) en la lucha biolgica contra Cosmopolites sordidus (Coleoptera: 398 Curculionidae). Proteccin de Plantas, 1, 15-21.

Dahlquist, R.M., Nilsa, A.C.A, Sanford, D.I.D. \& Hilje L. (2007). Movement patterns of the banana weevil (Cosmopolites sordidus Germar) in relation to its host plant. Annual Meeting,

\section{Entomological Society of America. December, 9-12.}

De Graaf, J., Govender, P., Schoeman, A.T.S. \& Viljoen A. (2005). Efficacy of pseudostem and pheromone seasonal trapping of the banana weevil Cosmopolites sordidus in South Africa. International Journal of Pest Management, 51, 209-218. DOI: 10.1080/09670870500228529.

Delattre, P. (1980). Recherche dune methode destimation des populations du charancon du bananier, Cosmopolites sordidus Germar (Col., Curculionidae). Acta Oecologica: Oecologia Applicata. 1, 83-92.

412 FAO. (2019). Banana Market Review 2018. Rome. www.fao.org/economic/est/estcommodities/bananas. Downloaded: 04/05/2020. 
415 Foagain, R., Messiaen, S. \& Foure E. (2002). Studies on the banana borer weevil in Cameroon. 416 Info Musa 11(1), 12.

417

418 Ghana Export Promotion Authority, 2017. Banana - Ghana's leading export markets. 419 - GEPA Exporters. www.gepaghana.org > market-report, banana-ghanas-l. Retrieved: $420 \quad 02 / 05 / 2020$.

421

422 Ghanaweb reports, (2018). https://www.ghanaweb.com/GhanaHomePage/business/Banana423 export-surges-to-70-000-tonnes-676613.

425 Gold, C.S., Pena, J.E. \& Karamura, E.B. (2003). Biology and integrated pest management 426 for the banana weevil Cosmopolites sordidus (Germar) (Coleoptera Curculionidae). In: 427 Control of Highland Bananas and Plantain Pests and Diseases. Integrated Pest Management 428 Reviews. Proceedings, Research Coordination Meeting, Cotonou 12-14 November 1991. IITA, 429 Ibadan. Kluwer Academic Publishers. Printed in the Netherlands.

Gold, C.S., Okech, S.H. \& Nokoe, S. (2002). Evaluation of pseudostem trapping as a control 432 measure against banana weevil, Cosmopolites sordidus (Coleoptera: Curculionidae) in 433 Uganda. Bulletin of Entomology Research, 92, 35-44. 
435 Gold, C.S., Pena, J.E. \& Karamura, E.B. (2001). Biology and integrated pest management for 436 the banana weevil Cosmopolites sordidus (Germar) (Coleoptera: Curculionidae). Integrated 437 Pest Management Reviews, 6, 79-155.

438

Gold, C.S., Rukazambuga, N.D.T.M., Karamura, E.B., Nemeye, P. \& Night G. (1999). Recent advances in banana weevil biology, population dynamics and pest status with emphasis on East Africa Pages 35-50. In: E.A. Frison, C.S. Gold, E.B. Karamura and R.A. Sikora, eds. Mobilizing IPM for sustainable banana production in Africa. INIBAP, Montpellier, France.

Gold, C.S. \& Bagabe, M.I. (1997). Banana weevil, Cosmopolites sordidus Germar (Coleoptera: Curculionidae), infestations of cooking- and beer-bananas in adjacent plantations in Uganda.

African Entomology. 5: 103-108.

Hallam, D. (1995). The world banana economy. Pp. 509-533. In: S. Gowen [ed.], Bananas and plantains. Natural Resources Institute and Department of Agriculture University of Reading. Chapman and Hall, London.

Hugo, C., Kenju, M., Toru, N. \& Klaus J. (1998). A synergistic aggregation pheromone component in the banana weevil Cosmopolites sordidus Germar 1894 (Coleoptera: Curculionidae). Acta Cientifica Venezolana, 49, 201-203. 
produced aggregation pheromone of the banana weevil Cosmopolites sordidus. Journal of

459

460

461

462

463

464

465

466

467

468

469

470

471

472

473

474

475

476

477

478

479

480

Chemical Ecology, 23, 1145-1161.

Kiggundu, A., Gold, C.S., Labuschagne, M.T., Vuylsteke, D. \& Louw S. (2003). Levels of host plant resistance to banana weevil, Cosmopolites sordidus (Germar) (Coleoptera: Curculionidae), in Ugandan Musa germplasm. Euphytica, 133, 267-277.

Kumakech, A. (2008). Reaction of Musa Balbisiana to Xanthomonas campestris Pv. Musacearum Infection. Msc. Thesis, Makerere University. December 2008.

Kumar, R., Jain, S., Meena, L.K. \& Sen, C. (2015). Resource Use Efficiency and Constraints in Production and Marketing of Tissue Culture and Sucker Propagated Banana. International Journal of Agricultural Science and Research, 5(5), 1-10.

Macharia, I., Kagundu, A.M., Kimani, E.W. and Otieno, W. (2010). Combating Phytosanitary Constraints to Banana (Musa spp.) Production: The Kenyan Example. Kenya Plant Health Inspectorate Service. Proc. IC on Banana \& Plantain in Africa Eds.: T. Dubois et al. Acta Horticulture, 879.

Masanza M., Gold C.S., van Huis A., Ragama P.E., Okech S.H.O., 2005. Effect of crop sanitation on banana weevil Cosmopolites sordidus (Germar) (Coleoptera: Curculionidae) populations and crop damage in farmers' fields in Uganda. Crop Protection, 24, 275-283. 
Mordor Intelligence (2019). Banana Market Size, Share, Analysis - Growth, Trends, and Forecast (2020-2025). mordorintelligence.com/industry-reports/banana.market.

Musabyimana, T., Saxena, R.C., Kairu, E.W., Ogol, C.P.K.O. \& Khan, Z.R. (2001). Effects of Neem Seed Derivatives on Behavioral and Physiological Responses of the Cosmopolites sordidus (Coleoptera: Curculionidae). Journal of Economic Entomology, 94, 449-454.

Nankinga, C.M. \& Moore, D. (2000). Reduction of banana Weevil populations using different formulations of the entomopathogenic fungus Beauveria bassiana. Biocontrol Science and Technology, 10, 645-657.

Ocan, D., Mukasa, H.H. Rubaihayo, P.R. Tinzaara, W. \& Blomme, G. (2008). Effects of banana weevil damage on plant growth and yield of East African Musa genotypes. Journal of Applied Biosciences 9 (2), 407-415.

Ortiz, R. \& Swennen, R. (2014). From cross breeding to biotechnology- facilitated improvement of banana and plantain. Biotechnology Advances, 32, 158-169.

Palanichamy, S., Padmanaban, B., Mohamed, M.I.F. \& Mustaffa, M.M. (2011). A simple and low cost semiochemical based trapping method for the management of banana pseudostem weevil, Odoiporus longicollis Olivier (Coleoptera: Curculionidae). Advance Applied Science Research, 2 (3), 69-73. 
504

505

506

507

508

509

510

511

512

513

514

515

516

517

518

519

520

521

522

523

524

525

526 Tinzaara, W., Gold, C.S., Kagezi, G.H., Dicke, M., Van Huis, A., Nankinga, C.M., 527

Price, N.S. (1994). Alternate cropping in the management of Radopholus similis and Cosmopolites sordidus, two important pests of banana and plantain. International Journal of Pest Management, 40, 237-244.

Reddy, G.V.P., Cruz, Z. T., Naz, F. \& Muniappan R. (2008). A pheromone-based trapping system for monitoring the population of Cosmopolites sordidus (Germar) (Coleoptera: Curculionidae). Journal of Plant Protection Research, 48, 515-527.

Somarriba, E. and Harvey, C.A. (2003). Como integrar producion sostenible y conservacion de biodiversidad en cacaotales organicos indegenas? Agroforestera en las Americas 10, 12-17.

Sponagel, K.W., Diaz, F.J. \& Cribas, A. (1995). El picudo negro del platano Cosmopolites sordidus: un insecto-plaga importante en cultivos del genero Musa y su estatus de peste en Honduras. FHIA, La Lima, Honduras. Pp. 34.

Stover, R.H. \& Simmonds, N.W. (1987). Bananas. Longman Scientific and Technical, New York.

Tewari, S., Leskey, T.C., Nielsen, A.L., Piñero, J.C. \& Rodriguez-Saona, C.R. (2014). Use of Pheromones in Insect Pest Management, with special attention to weevil pheromones. Current Concepts and Ecological Perspective. Integrated Pest Management, pp. 141-168.

Tushemereirwe, W. \& Ragama P.E. (2005). Effects of two pheromone trap densities against 
banana weevil, Cosmopolites sordidus, populations and their impact on plant damage in Uganda. Journal of Applied Entomology, 129, 265-271.

Tinzaara, W., Dicke, M., Van Huis, A., Van Loon, J.J.A. \& Gold, C.S. (2003). Different bioassays for investigating orientation responses of the banana weevil, Cosmopolites sordidus, show additive effects of host plant volatiles and a synthetic male-produced aggregation pheromone. Entomologia Experimentalis et Applicata, 106, 169-175.

Tinzaara, W., Dicke, M., Van Huis, A. \& Gold, C.S. (2002). Use of infochemicals in pest management with special reference to the banana weevil, Cosmopolites sordidus (Germar) (Coleoptera: Curculionidae). Insect Science and its Application, 22, 241-261.

Tóth M, Sivcev I, Tomasev I, Szarukán I, Imrei Z and Ujváry I, (2002). Development of a new pheromone trap design for capture of the sugar-beet weevil (Bothynoderes punctiventris Germar.) (Coleoptera, Curculionidae). Növényvédelem, 38, 145-152.

Treverrow, N.L., Bedding, R., Dettmann, E.B. \& Maddox C. (1991). Evaluation of entomopathogenic nematodes for the control of Cosmopolites sordidus Germar (Coleoptera: Curculionidae), a pest of bananas in Australia. Annals of Applied Biology, 119, 13945.

Twesigye, C.K., Ssekatawa, K., Kiggundu, A., Tushemereirwe, W., Matovu, E. \& Karamura, E.B. (2018). Corm damage caused by banana weevils Cosmopolites sordidus (Germar) collected from different banana growing regions in Uganda. Agriculture \& Food Security. 7(73). DOI: 10.1186/s40066-018-0224-y. 
553 Vidal, D.M., Moreira, M.A.B., Coracini, M.D.A. \& Zarbin, P.H.G. (2019). Isophorone 554 derivatives as a new structural motif of aggregation pheromones in Curculionidae. Scientific 555 Reports, 9, 776. DOI: 10.1038/s41598-018-37156-8.

556

557 Wertheim, B., van Baalen, E.J.A., Dicke, M., Vet, L.E.M. (2005). Pheromone-mediated 558 aggregation in nonsocial arthropods: an evolutionary ecological perspective. Annual Reviews 559 of Entomology, 50, 321-346.

560

561 Workman, D. (2020). World's top Banana exports, Bananas Exports by Country, 2019.

562 www.worldstopexports.com > bananas-exports-country.

563

564 Zhu, J. \& Park, K-C. (2005). Methyl salicylate, a soybean aphid-induced plant volatile 565 attractive to the predator Coccinella septempunctata. Journal of Chemical Ecology, 31, 17335661746. 


\section{Figure legends}

568 Figure 1. The type TAL modified trap (A), Voltic drinking water bottle trap (B) and

569 pseudostem (C) used in field trapping experiments with adult banana weevils, Cosmopolites

570 sordidus, in Ashanti region, Ghana.

571

572 Figure 2. Residual plots from ANOVA of logged trap catches per week data.

573

574 Figure 3. Overall mean ( \pm- SE) catch of banana weevils per week using different baits in TAL

575 and Voltic bottle traps.

576 